\title{
Offshore and nearshore chlorophyll increases induced by typhoon winds and subsequent terrestrial rainwater runoff
}

\author{
Guang Ming Zheng ${ }^{1,2}$, DanLing Tang ${ }^{1,2, *}$ \\ ${ }^{1}$ Laboratory for Tropical Marine Environment Dynamics (LED), Remote Sensing and Marine Ecology Group, \\ South China Sea Institute of Oceanology, Chinese Academy of Sciences, 164 West Xingang Road, Guangzhou 510301, China \\ ${ }^{2}$ Graduate School of the Chinese Academy of Sciences, 19A Yuquan Road, Beijing 100049, China
}

\begin{abstract}
The response of phytoplankton chlorophyll to Typhoon Damrey in the South China Sea (SCS) in September 2005 was studied by remote sensing. Chl a concentration increased in 2 areas after the typhoon: (1) An offshore bloom along Damrey's track exhibited a chl a peak (4 mg m $\mathrm{m}^{-3} 5 \mathrm{~d}$ after the typhoon's passage. It was preceded by sea-surface cooling $\left(-5^{\circ} \mathrm{C}\right)$, mainly on the right side of the typhoon track, and sea-level decrease $(-25 \mathrm{~cm})$ along the typhoon track $1 \mathrm{~d}$ post-typhoon. The offshore bloom was due to nutrient increase from mixing and upwelling. (2) A nearshore chl a increase succeeded typhoon rain (>300 $\mathrm{mm}$ on 26 September) on Hainan Island in the northwest $\mathrm{SCS}$. In the bloom region, the water was rich in suspended sediments, phytoplankton, and colored dissolved organic matter, and was entrained by an eddy. This nearshore feature may have resulted from rainwater discharge and seaward advection by a typhoon-induced current. By these 2 mechanisms, both typhoon winds and rain can enhance production of marine phytoplankton.
\end{abstract}

KEY WORDS: South China Sea · Typhoon Damrey · Ocean color · Remote sensing · Phytoplankton bloom

Resale or republication not permitted without written consent of the publisher

\section{INTRODUCTION}

Typhoons (or hurricanes, tropical cyclones) might play an important role in nourishing phytoplankton in the tropics and subtropics (Subrahmanyam et al. 2002, Lin et al. 2003, Babin et al. 2004, Walker et al. 2005). The South China Sea (SCS) is a tropical sea frequently subject to typhoons (Elsner \& Liu 2003, Wu et al. 2005). In September 2005, Typhoon Damrey (Category 2), the strongest typhoon over Hainan Island (HNI) in $32 \mathrm{yr}$, and south China in 10 yr (according to Xinhua News Agency), visited the northern SCS (Fig. 1) and led to 2 chl $a$ increases in large areas. This article reveals how a typhoon contributed to marine primary productivity.

With global warming, typhoon activity has been strengthening in both intensity and spatial coverage in the past several decades. Hurricane lifetimes and intensities are highly correlated with tropical sea-surface temperature (SST) (Emanuel 2005). Hurricane activity in the North Atlantic between 1995 and 2000 doubled compared with that between 1971 and 1994, as a result of concurrent increases in North Atlantic SST (Stanley et al. 2001). The Pacific Ocean and Indian Ocean also experienced increases in the number and proportion of super-hurricanes (Categories 4 and 5) with increasing SST over the past $35 \mathrm{yr}$ (Webster et al. 2005). In subtropical East Asia, typhoon activity also increased over the past 4 decades due to the westward shifts of 2 prevailing typhoon tracks in the western North Pacific (WNP) (Wu et al. 2005). Finally, the present high level of hurricane activity is predicted to persist for an additional 10 to 40 yr (Stanley et al. 2001).

Traditionally accepted mechanisms of nutrient supply are insufficient to explain geochemical estimates of 


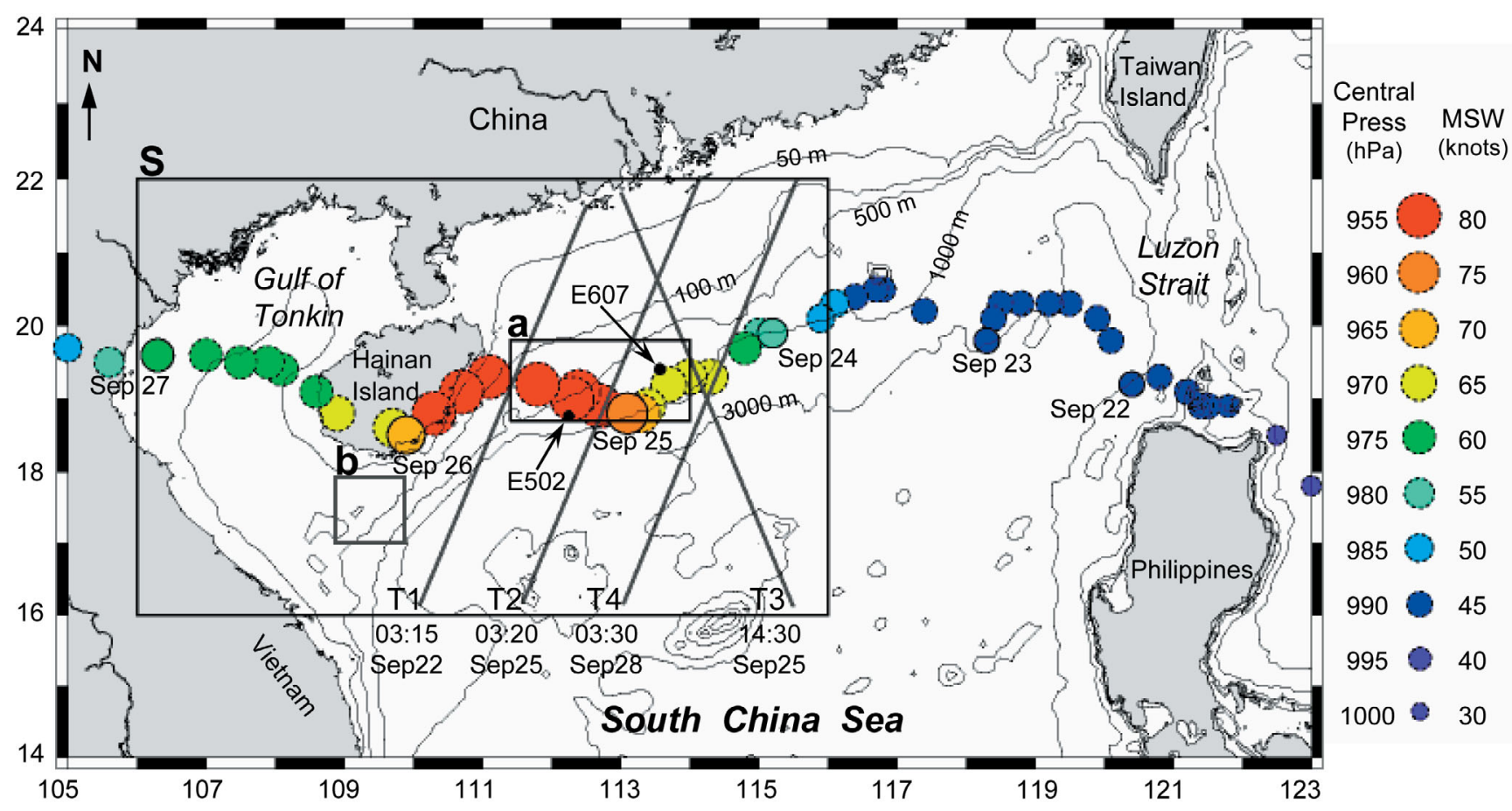

Fig. 1. Study area (Box S) and track of Typhoon Damrey. Typhoon center positions every $3 \mathrm{~h}$ are indicated by colored circles (circle color: central pressure $[\mathrm{hPa}]_{\text {; }}$ circle diameter: maximum sustained wind speeds [MSW, knots, $\left.1 \mathrm{knot}=0.514 \mathrm{~m} \mathrm{~s}^{-1}\right]$ ). Boxes a $\left(111.4-114^{\circ} \mathrm{E}, 18.7-19.8^{\circ} \mathrm{N}\right)$ and $\mathrm{b}\left(108.9-109.9^{\circ} \mathrm{E}, 17-17.9^{\circ} \mathrm{N}\right)$ are data sampling areas. Dates beside the typhoon center show 00:00 h of each day. T1 to T4: sea level anomaly transects. All dates and times are Coordinated Universal Time (UTC)

primary production (McGillicuddy et al. 1998, and references therein). One reason could be that ship measurements tend to under-sample episodic events such as mesoscale eddies (McGillicuddy et al. 1998). Other episodic events even more likely to be neglected by shipboard observation, however, are typhoons, which are furious, dangerous, and unpredictable (Lin et al. 2003). In fact, typhoons could enhance the biomass and change the community structure of phytoplankton (Chang et al. 1996) and reduce or enhance primary productivity in coastal waters (Fogel et al. 1999). Offshore phytoplankton responses to tropical cyclones were poorly known until recent application of ocean color satellites demonstrated that surface chl $a$ increased several days after a typhoon's passage (Subrahmanyam et al. 2002, Lin et al. 2003, Babin et al. 2004, Walker et al. 2005). Typhoons thus may play a role similar to cyclonic eddies in enhancing oceanic primary productivity in oligotrophic ocean waters (McGillicuddy et al. 1998, Ning et al. 2004), especially in typhoon-dominated seas such as the SCS. Studying phytoplankton response to typhoons would help to balance budgets of primary production and estimate phytoplankton feedback to global warming. Satellite remote sensing is a relatively effective tool to study typhoon-induced chl a variation. However, good-quality chl a imagery after a typhoon is still hard to obtain because of heavy cloud cover. Our knowledge about the effect of typhoons upon the phytoplankton is still scarce.

Open questions are, for example: What is the entire picture of the effect of a typhoon, including also its rain, upon phytoplankton? Is there a typical time lag of a phytoplankton bloom after the passage of a typhoon? What is the ecological effect of typhoon rain runoff? Is the rain ecologically unique in a turbulent coastal environment induced by a typhoon (e.g. setting up an offshore-directed current)? In September 2005, relatively small cloud coverage in the SCS after Typhoon Damrey provided a good opportunity to study the phytoplankton response using remote sensing data. We were able to obtain a complete picture of the typhoon's effects upon phytoplankton, which, in fact, occurred in 2 phases.

\section{STUDY AREA}

Typhoons in the SCS. The SCS is a typhoondominated tropical sea $\left(3^{\circ} 00^{\prime}\right.$ to $23^{\circ} 22^{\prime} \mathrm{N}, 99^{\circ} 10^{\prime}$ to $\left.122^{\circ} 10^{\prime} \mathrm{E}\right)$ and also the largest marginal sea of the western Pacific (Fig. 1). The prevailing track of typhoons in the WNP is westward over the northern 
SCS (Elsner \& Liu 2003, Wu et al. 2005). Also, the WNP is the region with the most numerous ( $36 \%$ of global annual average) and violent typhoons in the world (Ren et al. 2002).

Typhoons over HNI. HNI is influenced by the South East Asian monsoon (Ren et al. 2002, Tang et al. 2003). Annual precipitation on HNI ranges between 1500 and $2000 \mathrm{~mm}$. HNI is among the most typhoon-affected areas in China, and the percentage of typhoon precipitation to total precipitation in HNI is $>20 \%$ (averaged from 1957 to 1996; Ren et al. 2002).

Geography of HNI. HNI is situated in the northwestern SCS (Fig. 1), with a land area of $33900 \mathrm{~km}^{2}$. The topography of HNI includes highlands at the center surrounded by lowlands, which shortens the island's rivers and accelerates rainwater accumulation in the rivers, thus forming high flood peaks in a short time. Altogether, 38 rivers on HNI have a watershed area of $>100 \mathrm{~km}^{2}$. Among them, 6 rivers discharge on the south coast of HNI. Their total watershed comprises $4141 \mathrm{~km}^{2}$ and accounts for $12 \%$ of HNI's land area.

\section{DATA AND METHODS}

Typhoon track data. We used 2 kinds of typhoon track data in this study. (1) Track data taken every $3 \mathrm{~h}$, including center location, central pressure, and maximum sustained wind speeds (MSW), were used to plot the track of Typhoon Damrey (Fig. 1) using Generic Mapping Tools (GMT) (Wessel \& Smith 1998). The data were issued by the Japan Meteorological Agency (JMA) and obtained from the Typhoon Database of the National Institute of Informatics of Japan (http://agora. ex.nii.ac.jp). The climatology background of typhoon occurrence in SCS and its proportion to WNP were also searched from this typhoon database. (2) Track data taken every $6 \mathrm{~h}$, with typhoon categories on the SaffirSimpson scale, were used to identify the category of Typhoon Damrey. Data were issued by the US Joint Typhoon Warning Center (JTWC) and obtained from Unisys (http://weather.unisys.com).

Vertical profiles. Ship-measured conductivitytemperature-depth (CTD) data were adopted to present a background of hydrodynamics. The data were measured by Sea-Bird SBE 9 at 2 stations (E502 and E607 in Fig. 1) in the SCS $5 \mathrm{~d}$ before the passage of Typhoon Damrey (20 September 2005), during the Northern SCS Opening Research Cruise by RV 'Shiyan 3', South China Sea Institute of Oceanology, Chinese Academy of Sciences.

Ocean color products. Ocean color products were derived from the Moderate Resolution Imaging Spectroradiometer (Modis) onboard Aqua and from Sea-viewing Wide Field-of-view Sensor (SeaWiFS).
Chl a concentrations were obtained as the standard Level 2 products of Modis (OC3M algorithm, $1 \mathrm{~km} \times$ $1 \mathrm{~km}$ ) and SeaWiFS (OC4v4 algorithm, $4 \mathrm{~km} \times 4 \mathrm{~km}$ ) (O'Reilly et al. 2000). Satellite remote sensing of ocean color may be influenced by colored dissolved organic matter (CDOM) and suspended sediment (SS). Phytoplankton absorbs strongly at $443 \mathrm{~nm}$, CDOM absorbs strongly at $412 \mathrm{~nm}$, and SS scatters strongest from 550 to $600 \mathrm{~nm}$ (Sathyendranath 2000). Therefore, we processed the following 3 products to compare the relative amount of phytoplankton, CDOM (including detrital material), and SS in seawater: (1) the absorption coefficient of phytoplankton at $443 \mathrm{~nm},(2)$ the absorption coefficient of CDOM at $412 \mathrm{~nm}$, and (3) the particulate backscatter coefficient at $555 \mathrm{~nm}$ to denote SS. These variables were processed from SeaWiFS Level 1A data using the GSM01 Semi-Analytical Bio-Optical Model (Maritorena et al. 2002). Modis and SeaWiFS data were provided by NASA's Ocean Color Working Group (http://oceancolor.gsfc.nasa.gov/) and processed using the SeaWiFS Data Analysis System (SeaDAS) (Baith et al. 2001).

SST. Merged SST data from 2 microwave sensors were adopted to obtain cloud-free daily SST images. They were TRMM Microwave Imager (TMI) onboard the Tropical Rainfall Measuring Mission (TRMM) and the Advanced Microwave Scanning Radiometer (AMSRE) onboard Aqua. Spatial resolution is $0.25^{\circ} \times$ $0.25^{\circ}$. An advantage of microwave retrievals over the infrared SST observations is that SST can be measured through clouds accompanying a typhoon. Microwave retrievals are insensitive to both atmospheric water vapor and aerosols. TMI and AMSRE data were produced by Remote Sensing Systems sponsored by NASA's Earth Science Research, Education and Applications Solution Network (REASoN) DISCOVER Project and the AMSRE Science Team. Data are available at www.remss.com.

Sea-level anomaly (SLA). Altimeter data were derived from multi-sensors. (1) Geosat Follow-On (GFO) along-track data were used to plot SLA transects (T1 to T4 in Fig. 1) passing our study area before, during, and after the typhoon. The pre- or posttyphoon time refers to the difference between the time of each SLA overflight and the time at which the typhoon center crossed this SLA transect. (2) Multisensor SLA data within our sampling area (Box a in Fig. 1) were collected to study the response of SLA to Typhoon Damrey. These sensors were Jason-1, TOPEX/POSEIDON, GFO, ERS-2 and Envisat. Data were produced by the Colorado Center for Astrodynamics Research (CCAR) Global Near RealTime Altimeter Data Research Group (available at: http://argo.colorado.edu/ realtime). 
Sea-surface wind. Wind vector images and wind stress were used to study sea-surface wind. (1) QuikScat sea-surface wind vectors were employed to show the wind field of Typhoon Damrey. QuikScat data are produced by Remote Sensing Systems, sponsored by the NASA Ocean Vector Winds Science Team (available at www.remss.com). (2) Wind-stress data were processed by the Physical Oceanography Distributed Active Archive Center (PO.DAAC) Ocean Earth Science Information Partner (ESIP) Tool (POET), an interface developed by Ocean ESIP, a member of the ESIP Federation, under contract to NASA (available at: poet.jpl.nasa.gov).

Typhoon rainfall. The rainfall was estimated using TRMM data collected every $3 \mathrm{~h}$ with $0.25^{\circ} \times 0.25^{\circ} \mathrm{spa}-$ tial resolution. Daily precipitation regimes were computed as the sum of 8 accumulated rainfall estimates made every $3 \mathrm{~h}$. This analysis was carried out with TRMM Online Visualization and Analysis System (TOVAS). TOVAS was developed by the Goddard Earth Sciences (GES) and Distributed Active Archive Center (DAAC). Data are available at http://lake. nascom.nasa.gov/tovas/.

\section{RESULTS}

\section{Typhoons in the SCS}

Typhoon Damrey. Damrey intensified to its strongest level upon approaching HNI (Fig. 1). It became a Category 1/2 typhoon (on the SaffirSimpson scale) and traveled with $3.7 \mathrm{~m} \mathrm{~s}^{-1}$ between 09:00 h on 24 September and 18:00 h on 25 September. It made landfall on HNI at 18:00 h on 25 September and traveled over land for $>13 \mathrm{~h}$ before leaving for the Gulf of Tonkin.

Typhoon climatology. Typhoons occur frequently in the SCS (Fig. 2). Altogether 592 typhoons passed the SCS from 1951 to 2005, accounting for $40 \%$ of all typhoons in the WNP (1468). Annually, 10.8 typhoons visit the SCS on average (1951 to 2005). The main typhoon season (June to November) accounts for $86 \%$ of total typhoon events, among which September ranks at the top.

Vertical profiles before Damrey. The mixed layer depth (MLD) before Typhoon Damrey was about $40 \mathrm{~m}$ (Fig. 3). Barrier layers, which are common in the tropical ocean surface, were not found in the profiles.

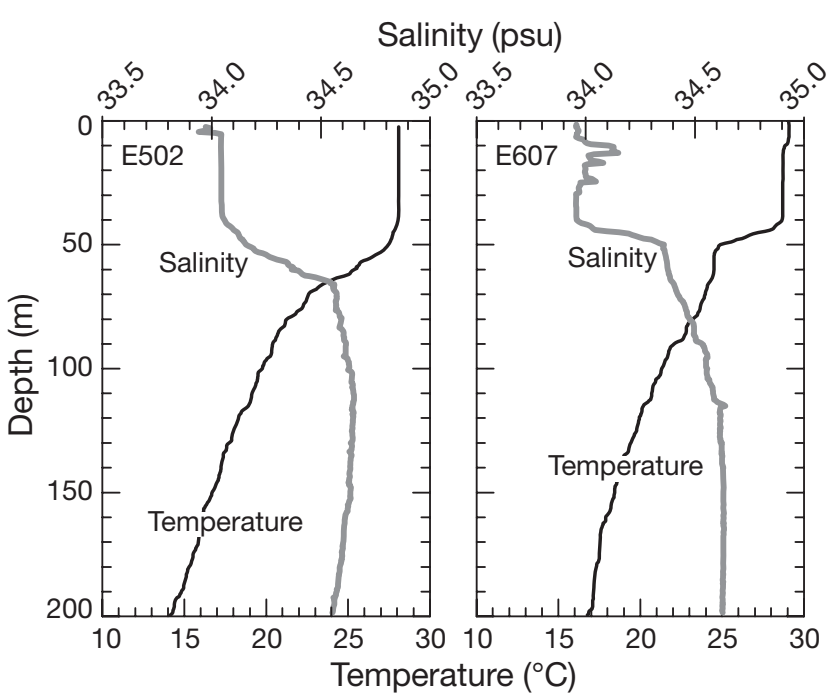

Fig. 3. Vertical profiles of temperature and salinity at 2 stations (E502 and E607 in Fig. 1) in the SCS 5 d (20 September 2005) before the passage of Typhoon Damrey

\section{Episodic chl a enhancement after Damrey}

After Typhoon Damrey (Fig. 4A), chl a increased at 2 locations: an offshore patch appeared along the typhoon track ('a' in Fig. 4B1) and a nearshore patch to the south of HNI ('b' in Fig. 4B1). The offshore patch lay between $\sim 70$ and $380 \mathrm{~km}$ to the east of HNI and reached maximum chl a values $>3 \mathrm{mg} \mathrm{m}^{-3}$. It was separated from shelf waters by a low chl a filament parallel to the coastline. The nearshore patch was connected with coastal waters and stretched about $140 \mathrm{~km}$ seaward. It showed a seaward gradient and an eddy shape with 2 filaments, suggesting that it might have been entrained in an eddy. These $2 \mathrm{chl}$ a anomalies were not present in the same periods of previous years (Fig. 4B2). 


\section{A. Typhoon Damrey}
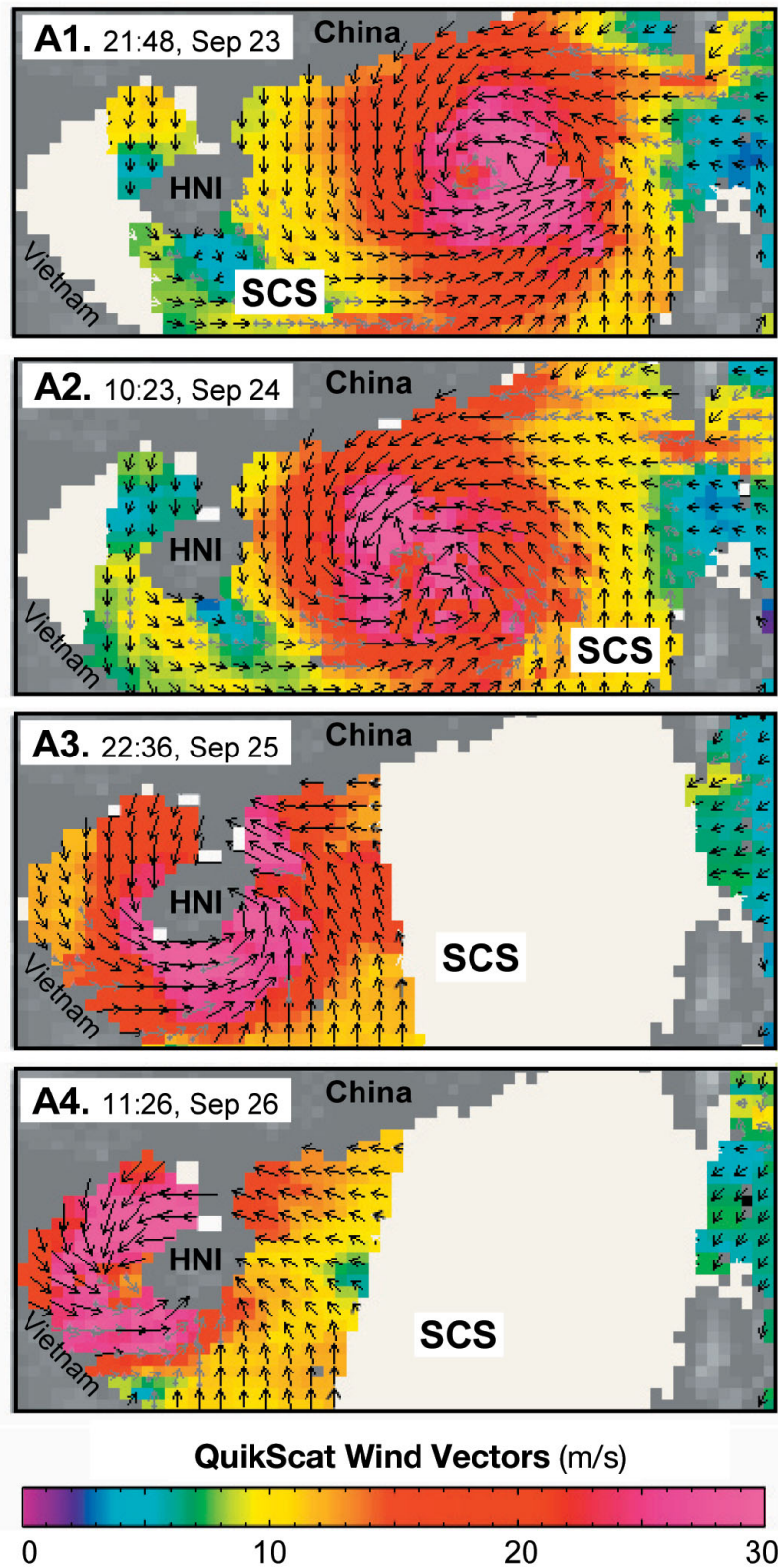

\section{Offshore chl a patch}

Sea-surface cooling. TMI-AMSRE SST data show sea-surface cooling after the typhoon passage (Fig. 5A). The northern SCS was dominated by water $>28^{\circ} \mathrm{C}$ prior to Typhoon Damrey (Fig. 5A1). Initial SST decreases $\left(0.5\right.$ to $2^{\circ} \mathrm{C}$ ) accompanied the typhoon passage (Fig. 5A3-5). The largest SST decrease (4 to $5^{\circ} \mathrm{C}$ ), however, occurred during the period of greatest strength of the typhoon (>Category 1), mainly to the right of its track, and $1 \mathrm{~d}$ after the typhoon's passage ('a' in Fig. 5A6).

\section{B. Post-typhoon Chl-a}
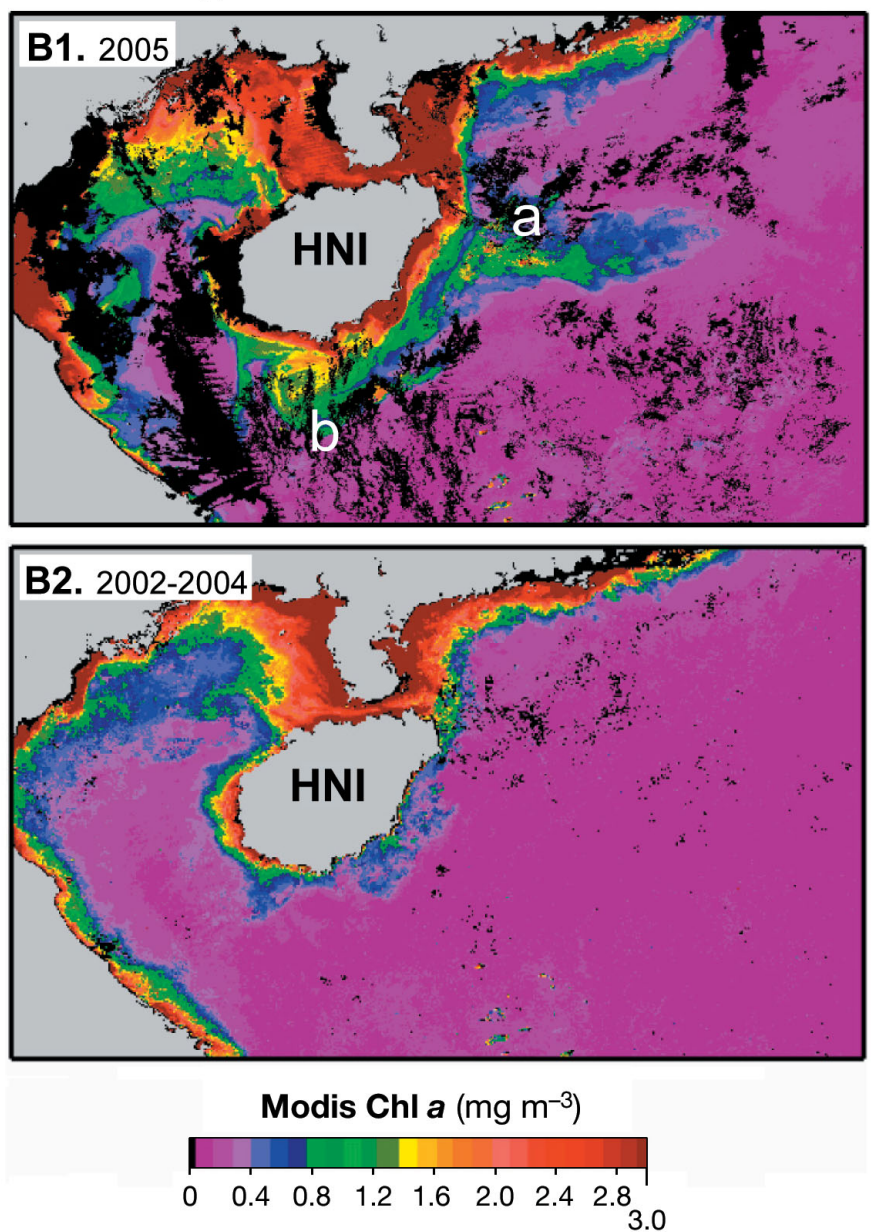

Fig. 4. (A) QuikScat wind-vector snapshots showing Typhoon Damrey (A1, A2) approaching, (A3) landing at, and (A4) leaving Hainan Island (HNI) (white area: no data). (B) Appearance of chl $a$ anomalies in 2005, shown by comparing weekly (28 September to 4 October) mean chl a concentrations between (B1) 2005 and (B2) 2002 to 2004; a: offshore chl a increase in the shape of a tongue; b: a nearshore chl a increase in an eddy pattern after the passage(black area: no data)

Sea-level decrease. Sea-surface cooling was accompanied by a sea-level decrease in the track of Damrey (Fig. 6C). GFO altimeter data showed a $100 \mathrm{~km}$ long low SLA $(-25 \mathrm{~cm})$ segment at the typhoon center $1 \mathrm{~d}$ after the passage of the typhoon (Fig. 6C). The lowSLA segment matched the sea surface cooling patch in terms of location and time. Sea level at the typhoon center during the typhoon was high (42 cm on average) and extended $55 \mathrm{~km}$ (Fig. 6B).

Gradual chl a increase. Chl a concentrations in the typhoon track increased step by step for $3 \mathrm{~d}$ during 28 to 30 September (Figs. 5B8-10 \& 7D). Chl a concentrations 
A

TMI-AMSRE SST $\left({ }^{\circ} \mathrm{C}\right)$
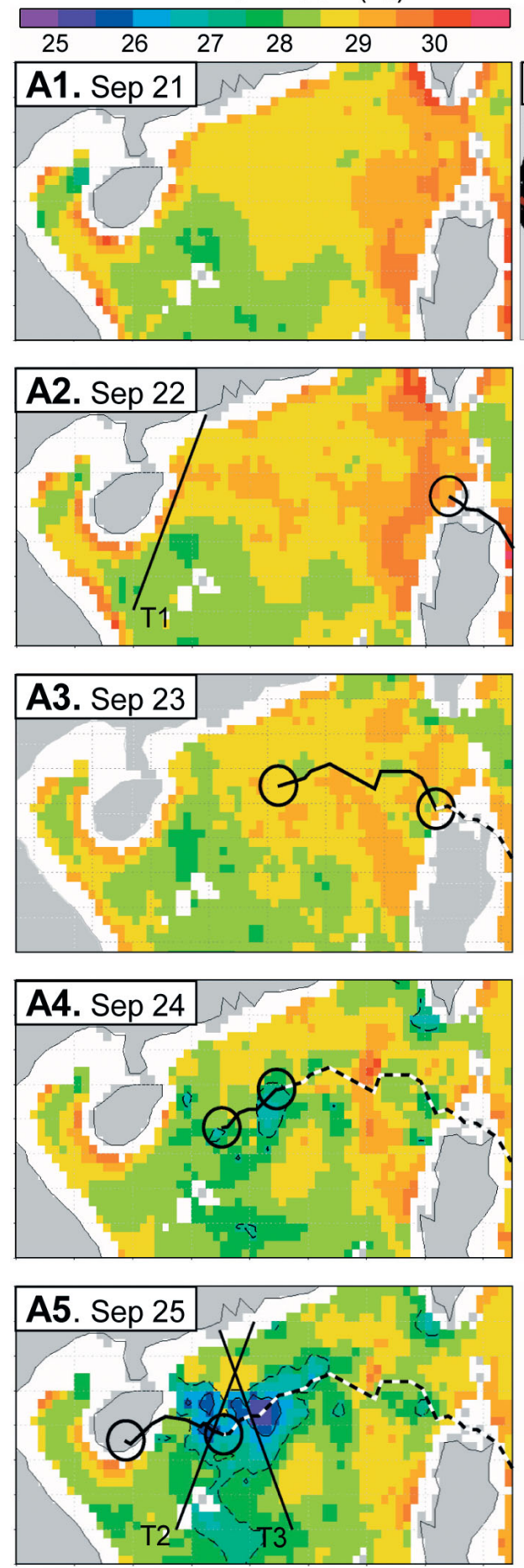

B

Chl a $\left(\mathrm{mg} \mathrm{m}^{-3}\right)$

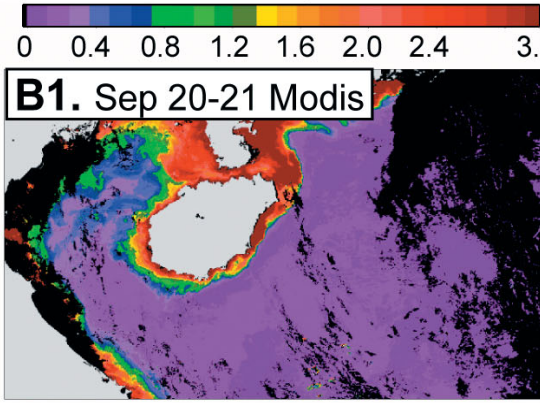

C

TRMM Rainfall (mm)

\begin{tabular}{cccccc}
\hline & & & $\mid$ & $\mid$ & $\mid$ \\
\hline 0 & 60 & 120 & 180 & 240 & 300
\end{tabular}
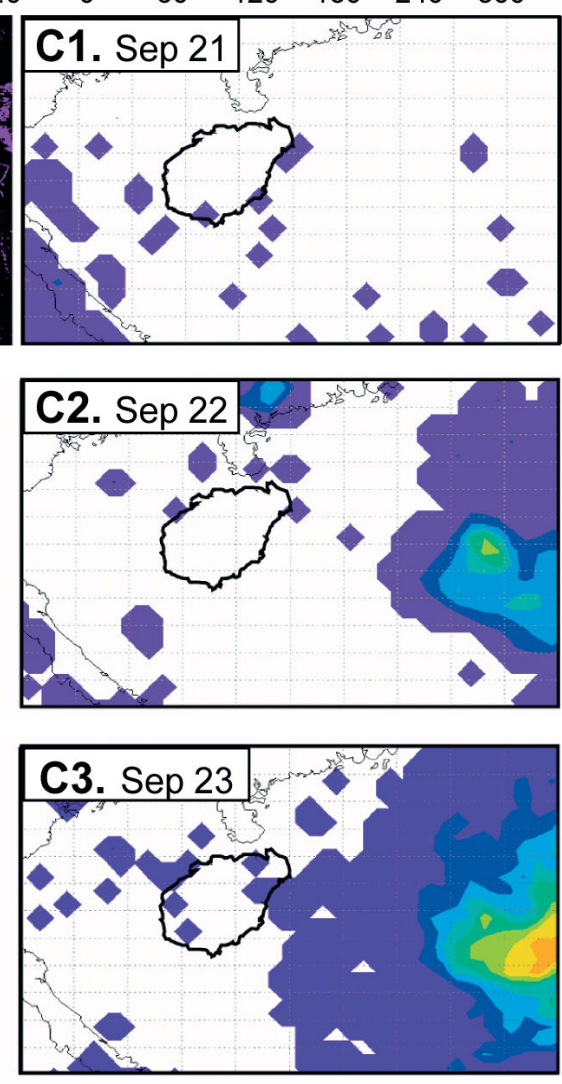

\section{No}

data
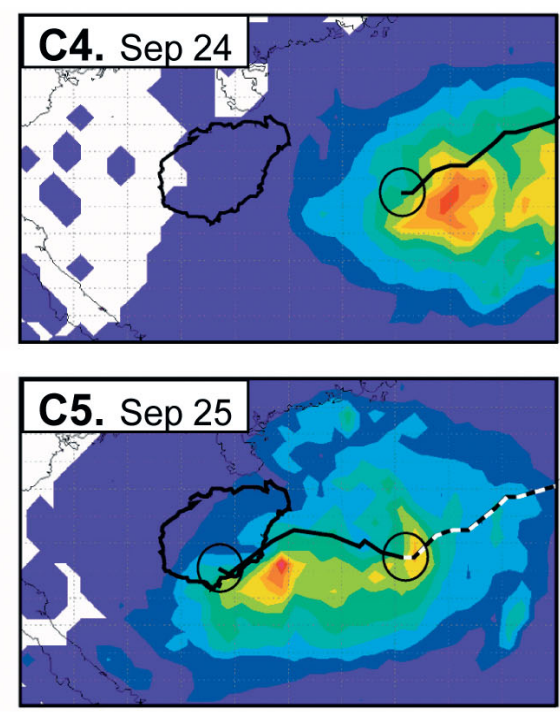

Fig. 5. Sea-surface cooling, chl a increase, and rainfall related to Typhoon Damrey 2005. (A) Sea-surface cooling in the track of Typhoon Damrey detected by TMI \& AMSRE. The $26^{\circ} \mathrm{C}$ isotherm is a black solid line; the $27.5^{\circ} \mathrm{C}$ isotherm is a dashed line. Transects T1 to T4 correspond to Fig. 4 (color scale: sea-surface temperature [SST, ${ }^{\circ} \mathrm{C}$ ]. (B) Modis and SeaWiFS chl $a$ increase after the typhoon (color scale: chl a $\left[\mathrm{mg} \mathrm{m}^{-3}\right]$ ). (C) TRMM daily rainfall showing westward movement of precipitation with the typhoon. Maximum rainfall occurred over the southern tip of HNI (arrow in C6) (color scale: daily rainfall [mm]). The typhoon track is indicated as a black solid line with circles at the starting and ending points for the present day and as a black-and-white dashed line for days passed (black and white areas: no data) 
A

TMI-AMSRE SST $\left({ }^{\circ} \mathrm{C}\right)$
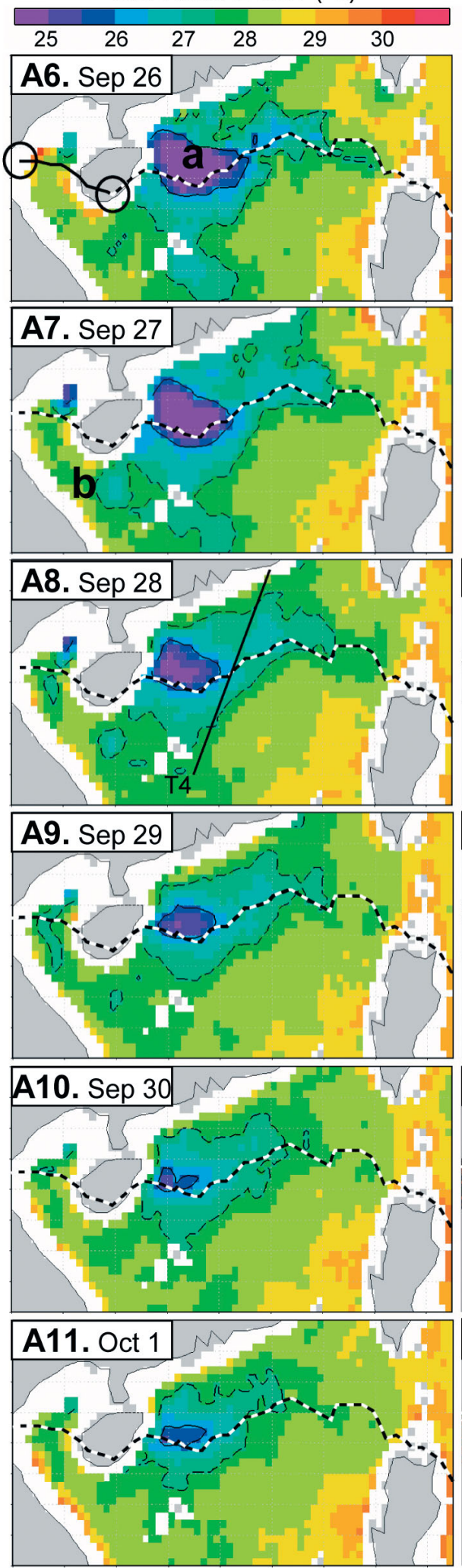

B

Chl a $\left(\mathrm{mg} \mathrm{m}^{-3}\right)$
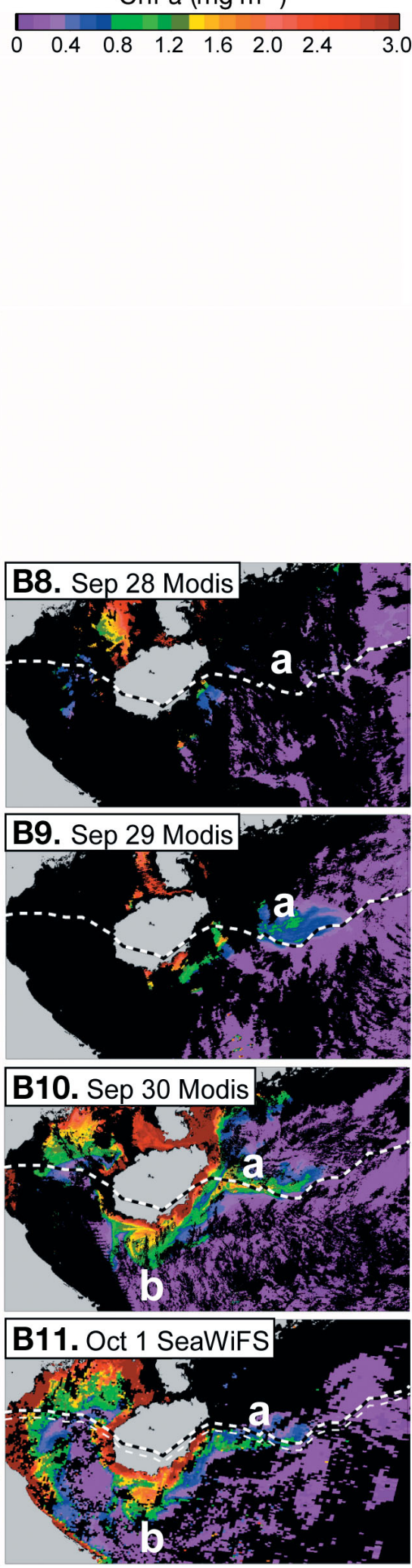

C

TRMM Rainfall (mm)

\begin{tabular}{rrrrrrr}
- & & & $\mid$ & $\mid$ & \\
\hline 0 & 60 & 120 & 180 & 240 & 300
\end{tabular}
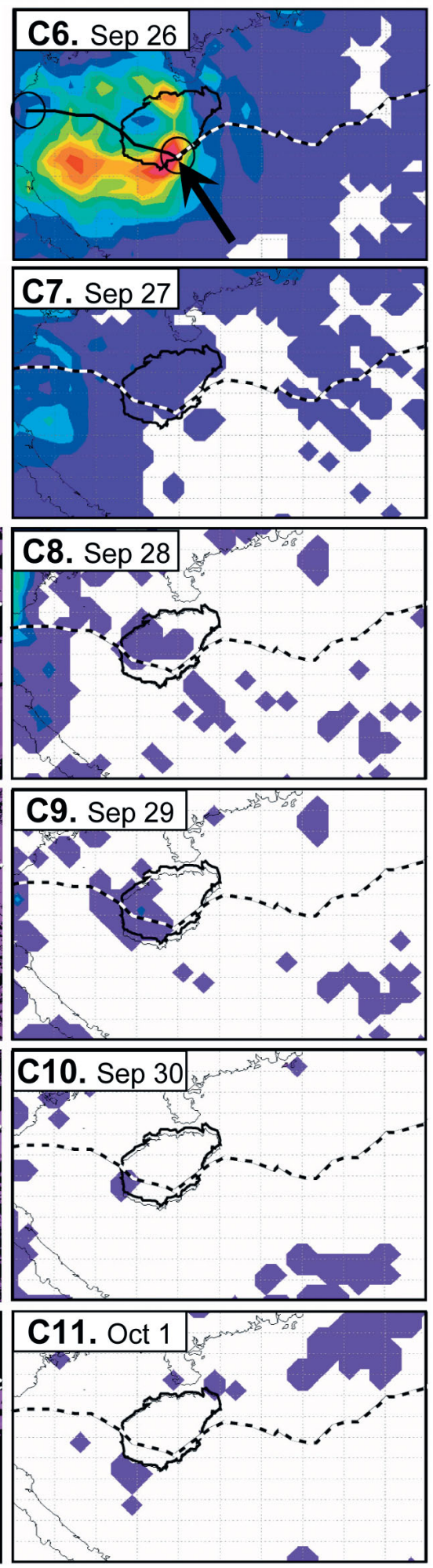

Fig. 5 (continued) 


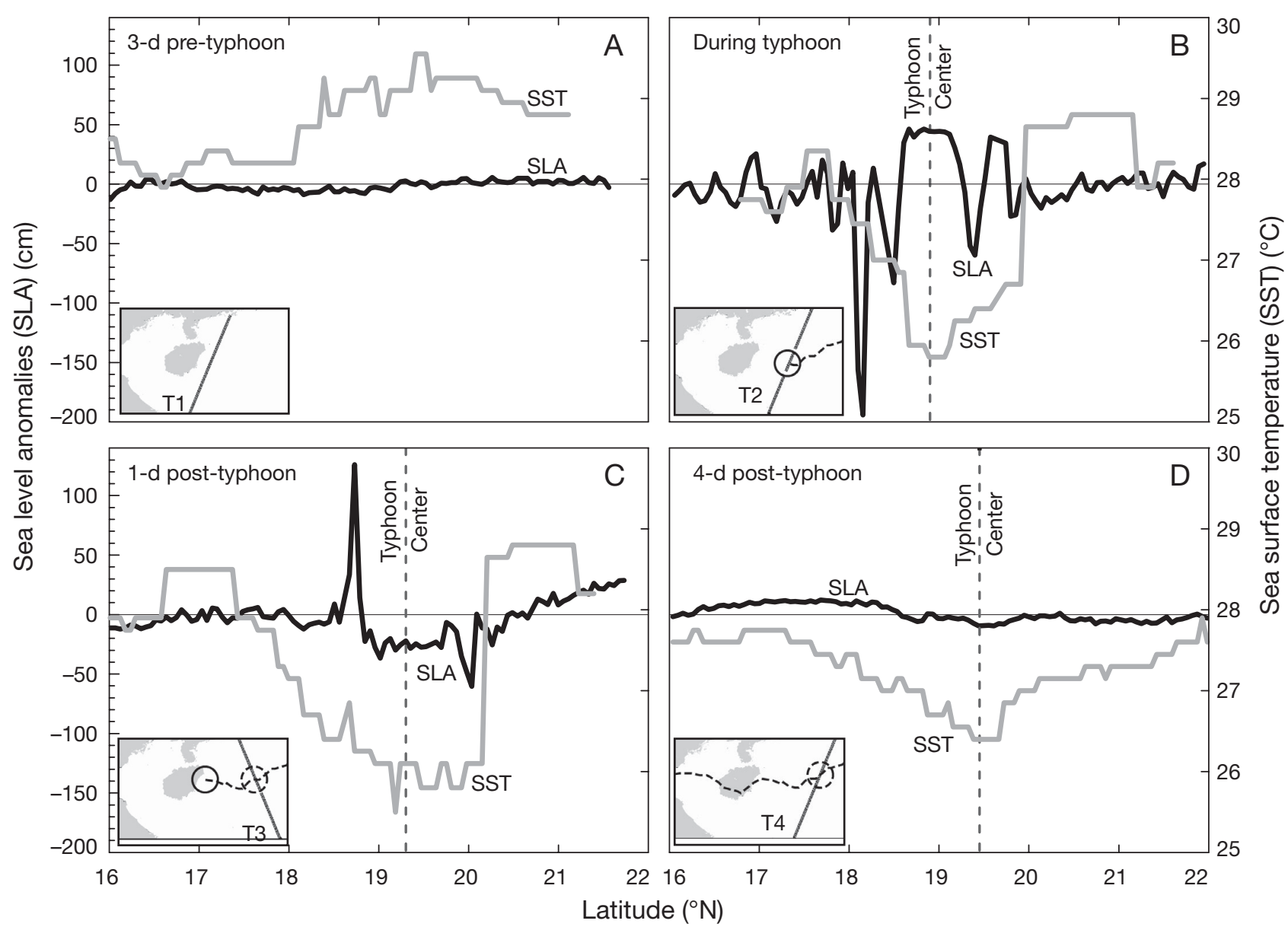

Fig. 6. GFO SLA (Geosat Follow-On, sea-level anomaly) transects measured (A) 3 d before, (B) during, (C) $1 \mathrm{~d}$ after, and (D) $4 \mathrm{~d}$ after typhoon. TMI-AMSRE SST data measured along the same transect and on the same day (not precisely the same time) with SLA are overlaid. SLAs in the typhoon centers were high during the typhoon and low $1 \mathrm{~d}$ after the typhoon. Low SLA matched low SST in the track of the typhoon. Insets: GFO transects and location of present typhoon center (solid circle) and past center (dashed circle); see Fig. 1 for overview.

were $<0.15 \mathrm{mg} \mathrm{m}^{-3}$ prior to typhoon passage (Fig. 5B1). $\mathrm{Chl}$ a in the typhoon track increased to about $0.3 \mathrm{mg} \mathrm{m}^{-3}$ ('a' in Fig. 5B8) on 28 September and to $1.0-1.9 \mathrm{mg} \mathrm{m}^{-3} \times$ $700 \mathrm{~km}^{2}$ ('a' in Fig. 5B9) on 29 September. It is very likely that the area of the bloom was significantly underestimated, since we could not observe much of the area due to cloud cover. Chl a levels $>1 \mathrm{mg} \mathrm{m}^{-3}$ expanded to $5800 \mathrm{~km}^{2}$ on 30 September ('a' in Fig. 5B10), and the peak value reached $4.1 \mathrm{mg} \mathrm{m}^{-3}$ at the axis.

Chl a enhancement was coupled with SST decrease in the track of the typhoon. The location of maximum chl a increase coincided with the greatest cooling (' $a$ ' in Fig. 5A6) and also appeared to the right of the typhoon track at first ('a' in Fig. 5B9), although thereafter it advected southward ('a' in Fig. 5B10-11). The chl a peak lagged the passage of the typhoon by $5 \mathrm{~d}$; the wind-stress peak, by $6 \mathrm{~d}$; and the lowest SST, by $4 \mathrm{~d}$ (Fig. 7). The optical signal from phytoplankton increased more significantly than CDOM and SS (Tables 1 \& 2, 'a' in Fig. 8A).

\section{Nearshore SS, phytoplankton, and CDOM}

Typhoon rain. Major precipitation accompanied Typhoon Damrey and predominantly fell to the left of the typhoon track (Fig. 5C4-6). The most intensive storm rain (>300 $\mathrm{mm}$ on 26 September) fell at the south tip of HNI (arrow in Fig. 5C6). SST declined by $0.6^{\circ} \mathrm{C}$ nearshore south of HNI ('b' in Fig. 5A7), $1 \mathrm{~d}$ after this heavy rain.

Chl a anomaly, SS, and CDOM. The first cloud-free image $4 \mathrm{~d}$ after the typhoon passage revealed a high chl a anomaly (b in Fig. 3B10) at the same location as the weak sea-surface cooling. Modis retrieved chl a concentrations enhanced up to $1.9 \mathrm{mg} \mathrm{m}^{-3}$. This anomaly was also captured by SeaWiFS on 1 October ('b' in Fig. 5B11). The water optical property of this chl a anomaly was complex. SS increase was highest, while phytoplankton and CDOM also increased significantly (Tables 1 \& 2, Fig. 8B). 


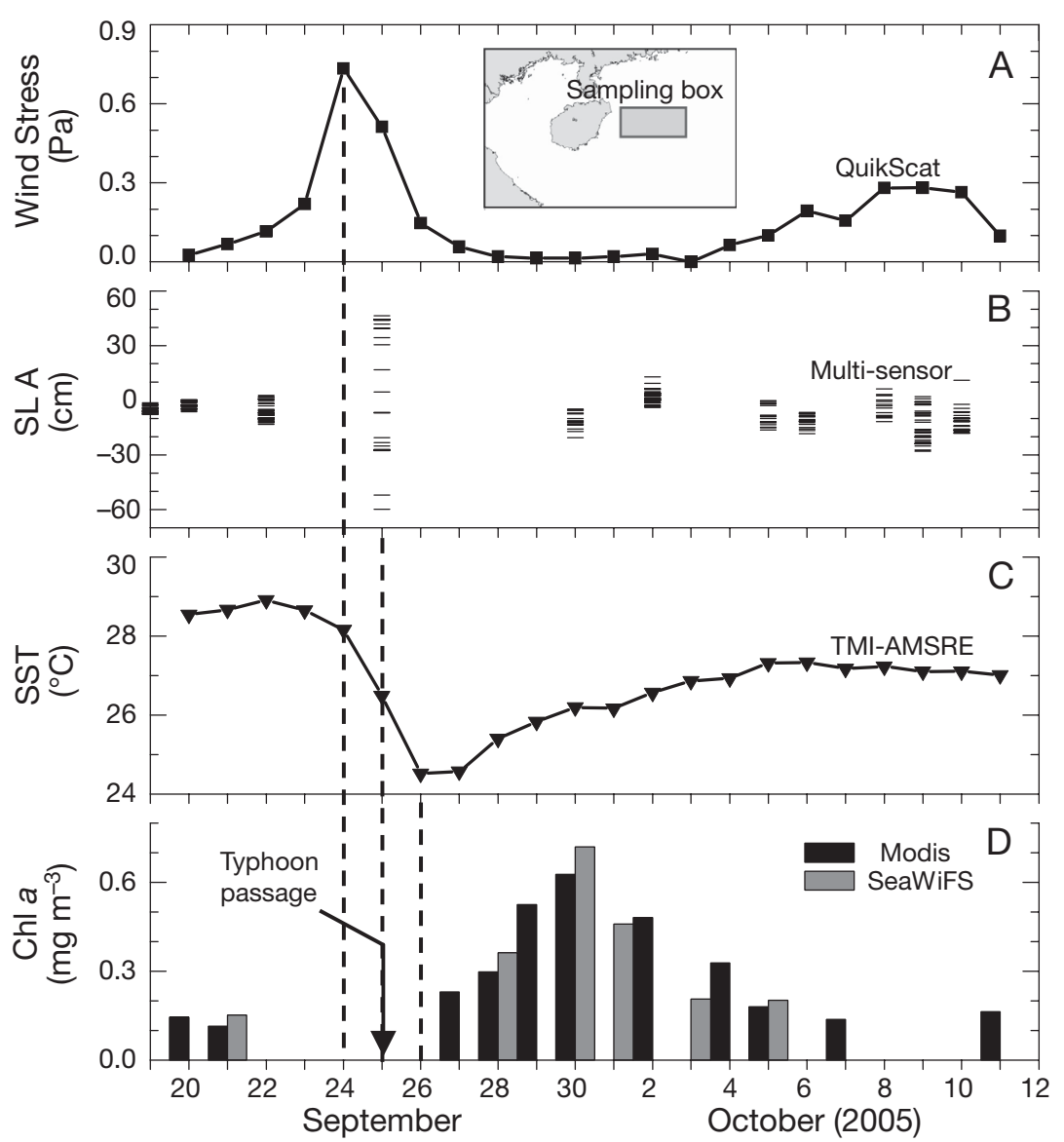

Fig. 7. Typhoon-induced sea-level variation, SST decrease, and chl a peak along the track. (A) QuikScat wind speeds exhibit a high peak on 24 September. (B) Multi-sensor (see details in 'Data and methods') sea level anomaly variations display the largest range on 25 September. (C) TMI-AMSRE SST declined to minimum on 26 September. (D) Modis and SeaWiFS chl a peak appeared on 30 September, $5 \mathrm{~d}$ following typhoon passage. Data were collected in the sampling box (also Box a in Fig. 1A)

Table 1. Biological, optical, and physical properties of the $2 \mathrm{chl}$ a anomalies after Typhoon Damrey, September 2005. B and A: values before (20 to 22 September) and after (30 September to 1 October) typhoon passage, respectively; $a_{p}(443)$ : phytoplankton absorption at $443 \mathrm{~nm}_{i} b_{s}(555)$ : suspended sediment (SS) backscatter at $555 \mathrm{~nm} ; a_{y}(412)$ : colored dissolved organic matter (CDOM) absorption at $412 \mathrm{~nm}$; SST: sea-surface temperature; SLA: sea level anomaly

\begin{tabular}{|lcccccc|}
\hline & $\begin{array}{c}\mathrm{Chl} a \\
\left(\mathrm{mg} \mathrm{m}^{-3}\right)\end{array}$ & $\begin{array}{c}a_{p}(443) \\
\left(10^{-3} \mathrm{~m}^{-1}\right)\end{array}$ & $\begin{array}{c}b_{s}(555) \\
\left(10^{-3} \mathrm{~m}^{-1}\right)\end{array}$ & $\begin{array}{c}a_{Y}(412) \\
\left(10^{-2} \mathrm{~m}^{-1}\right)\end{array}$ & $\begin{array}{c}\text { SST } \\
\left({ }^{\circ} \mathrm{C}\right)\end{array}$ & $\begin{array}{c}\text { SLA } \\
(\mathrm{cm})\end{array}$ \\
\hline Offshore & & & & & & \\
B & 0.129 & 7.07 & 1.56 & 1.78 & 28.9 & -0.9 \\
A & 0.626 & 29.02 & 2.47 & 3.83 & 24.5 & -26.3 \\
A-B (A/B) & $0.497(4.9)$ & $21.95(4.1)$ & $0.91(1.6)$ & $2.05(2.2)$ & -4.4 & -25.4 \\
Nearshore & & & & & & \\
B & 0.155 & 7.78 & 1.18 & 2.59 & 28.2 & \\
A & 1.05 & 49.05 & 12.13 & 8.98 & 27.6 & \\
A-B (A/B) & $0.895(6.8)$ & $41.27(6.3)$ & $10.95(10.3)$ & $6.39(3.5)$ & -0.6 & \\
\hline
\end{tabular}

\section{DISCUSSION}

We observed $2 \mathrm{chl} a$ anomalies in the northwestern SCS following the passage of Typhoon Damrey: (1) an offshore chl $a$ increase ('a' in Fig. 4B1) along the typhoon track and (2) a nearshore chl $a$ anomaly ('b' in Fig. 4B1) near the largest rainfall area on HNI.

\section{Offshore phytoplankton bloom}

Phytoplankton bloom

The increase of phytoplankton absorption dominated among the enhancements of 3 optical properties in the offshore chl $a$ anomaly (Tables $1 \&$ 2 , ' $\mathrm{a}$ ' in Fig. 8). The chl a concentration increased gradually instead of being a sudden boost immediately after typhoon passage ('a' in Figs. 5B8-10 \& 7D), and thus was unlike the quick SST decrease (Fig. 7C). This indicates that the offshore chl $a$ increase was not due to physical entrainment from a deep chlorophyll maximum. Although CDOM and SS signals also increased after the passage of the typhoon, their absolute values remained at a low level (Tables $1 \& 2$ ). Of course, the 3 fold increase of phytoplankton absorption (Tables $1 \& 2$ ) may explain the doubling of CDOM to some extent, since phytoplankton produces CDOM (Sathyendranath 2000). The chl a increase was unlikely to have been horizontally transported from coastal water, since a low chl a filament was observed between coastal and offshore waters. Thus, the offshore chl a anomaly is most likely a phytoplankton bloom due to in situ phytoplankton growth fueled by new nutrients introduced into the euphotic zone from below.

\section{Vertical mixing and upwelling}

The initial phytoplankton bloom (' $\mathrm{a}$ ' in Fig. 5B9) and the greatest sea-surface cooling ('a' in Fig. 5A6) appeared mainly to the right of the typhoon track. This 
Table 2. Summary of characteristics of the 2 phytoplankton blooms induced by the passage of Typhoon Damrey. CDOM: colored dissolved organic matter; SS: suspended sediment; HNI: Hainan Island

\begin{tabular}{|lccc|}
\hline Amplitude increase & Location & Area (km²) & Mechanism \\
\hline $\begin{array}{l}\text { Offshore ('a' in Fig. 8) } \\
\text { Phytoplankton > CDOM > SS }\end{array}$ & Track of typhoon & 33000 & Upwelling and vertical mixing ('a' in Fig. 9) \\
$\begin{array}{l}\text { Nearshore ('b' in Fig. 8) } \\
\text { SS > phytoplankton > CDOM }\end{array}$ & $\begin{array}{c}\text { Near the largest } \\
\text { rainfall area of HNI }\end{array}$ & 10000 & $\begin{array}{r}\text { Precipitation, rainwater runoff and advection } \\
\text { of SS and phytoplankton ('b' in Fig. 9) }\end{array}$ \\
\hline
\end{tabular}

\section{A. Phytoplankton}
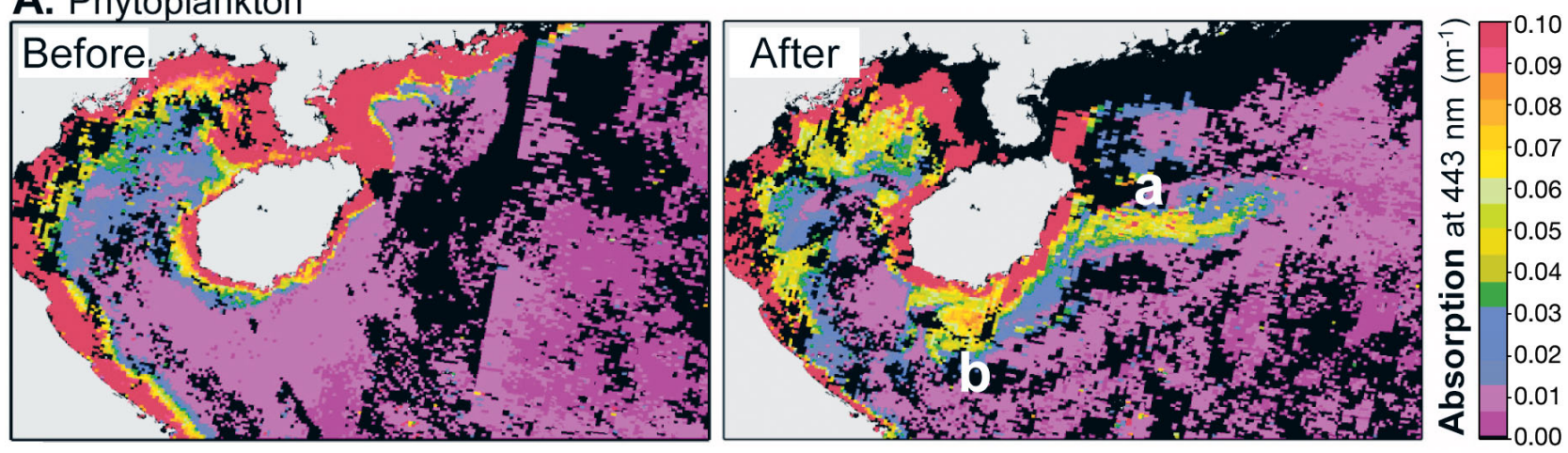

\section{B. Suspended sediment}
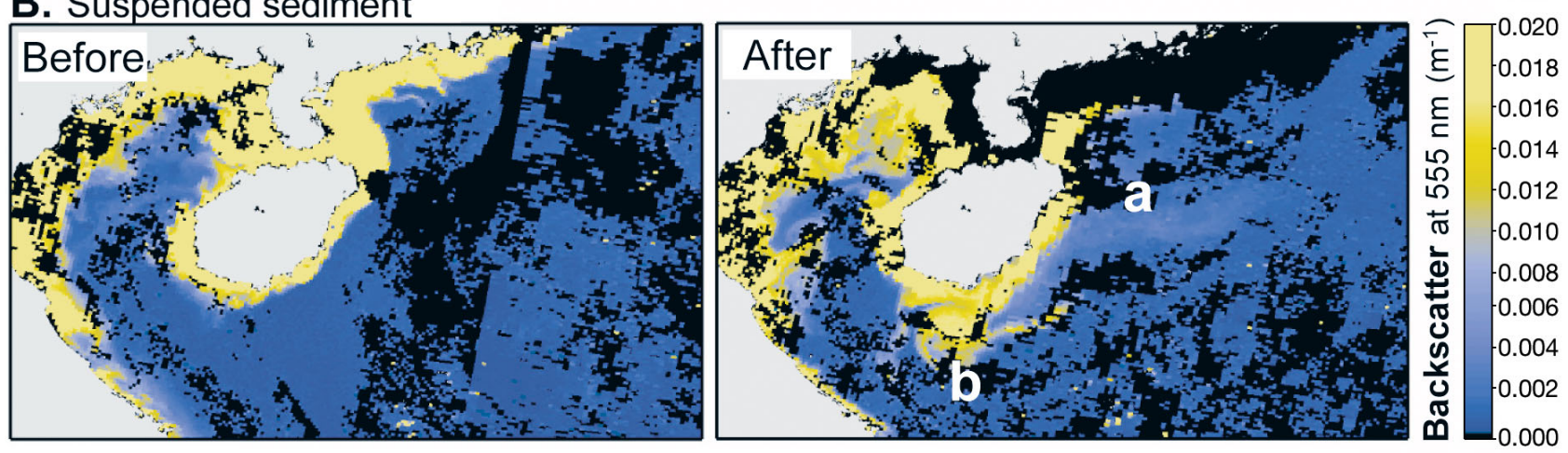

\section{CDOM}
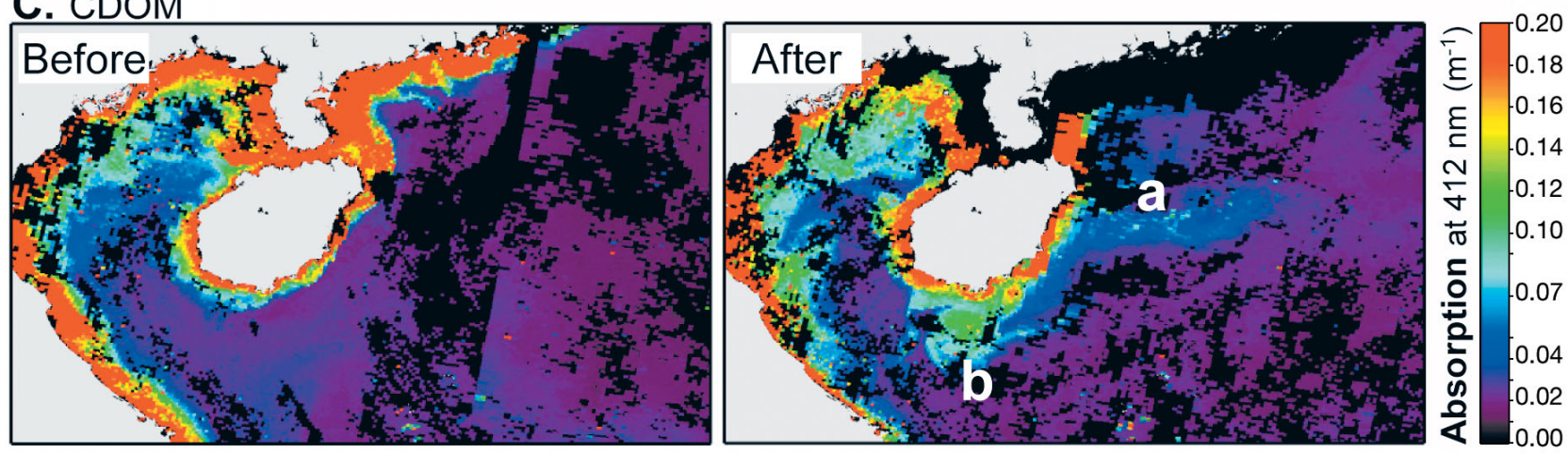

Fig. 8. Distribution of (A) absorption by phytoplankton, (B) backscatter by suspended sediment, and (C) absorption by colored dissolved organic matter (CDOM) in the northeastern SCS before and after typhoon passage. Data were derived from SeaWiFS data from 20 and 21 September (before) and 30 September and 1 October (after) 2005, using GSM01 Semi-Analytical Bio-Optical Model (a and b: eddy patterns described in Fig. 4 legend) 
asymmetry of a phytoplankton bloom after a typhoon was seldom documented before in the SCS. It may have been caused by more intense winds to the right of the typhoon track, resulting in greater vertical mixing (Price 1981). Vertical mixing is a common nutrient injection process (Tang et al. 2003, 2006) during typhoons (Subrahmanyam et al. 2002, Lin et al. 2003). Both low SST and low SLA (Fig. 6C) appeared in the track of Typhoon Damrey $1 \mathrm{~d}$ after its passage. Sea-surface cooling and sea-level decrease are typical features for upwelling areas, because deep waters are cold and declining SLA are generally correlated with shoaling isopycnals or upwelling (McGillicuddy et al. 1998, Tang et al. 2004a,b). Phytoplankton blooms supported by upwelling-induced nutrients connected with typhoons have been observed in the Gulf of Mexico (Walker et al. 2005) and in the SCS (Lin et al. 2003). The upwelling could be due to divergence of seawater forced by wind and low barometric pressure in the typhoon center (Price 1981). The upwelled deep-layer water (or subsurface water) mixed with upper-layer seawater, injecting nutrients into the euphotic zone in the track of the typhoon, and finally induced the phytoplankton bloom. Therefore, a combination of both vertical mixing and upwelling might have supplied nutrients for the phytoplankton bloom. This suggestion agrees with the mechanism proposed by Lin et al. (2003) for the phytoplankton bloom triggered by Typhoon Kai-Tak in the SCS from 5 to 8 July 2000. Both Damrey (3.7 $\mathrm{m} \mathrm{s}^{-1}$ ) and Kai-Tak (0 to $1.4 \mathrm{~m} \mathrm{~s}^{-1}$ ) had a translation speed of $<4 \mathrm{~m} \mathrm{~s}^{-1}$. At such a speed, upwelling occurs and enhances vertical mixing (Price 1981).

Time lag

The offshore phytoplankton bloom appeared $5 \mathrm{~d}$ after the passage of Typhoon Damrey (Fig. 5). By reviewing recent studies on time lags between phytoplankton blooms (induced by vertically injected nutrients) and their preceding typhoons (Table 3), we found that the time lags ranged from 3 to $6 \mathrm{~d}$. Detailed factors affecting the time lag are complicated and beyond the scope of this study; however, 3 points require further investigation.

(1) The rate of upwelling, related to the wind and translation speeds of a typhoon. Summer coastal upwelling velocity east of HNI is about 6.3 to $50 \times 10^{-4}$ $\mathrm{cm} \mathrm{s}^{-1}$ at a wind speed of 5 to $7 \mathrm{~m} \mathrm{~s}^{-1}$ (Wu 1990). Typhoon wind, however, is much stronger $\left(>30 \mathrm{~m} \mathrm{~s}^{-1}\right)$, and the typhoon center is always shifting $\left(3.7 \mathrm{~m} \mathrm{~s}^{-1}\right.$ or $13 \mathrm{~km} \mathrm{~h}^{-1}$ for Damrey).

(2) The amount of nutrient injected into the euphotic layer, related to the nutrient availability below the mixed layer, and the intensity and duration of vertical mixing and upwelling.

(3) The rate of nutrient uptake by phytoplankton, related to the inherent uptake rate, phytoplankton standing stock coupled with underwater irradiance (often limited by heavy cloud during and after a typhoon), losses from grazing and mixing, and the resulting population growth rate.

\section{Threshold bloom-triggering wind speed (TBW)}

Why did the phytoplankton bloom only appear at the location of the typhoon's highest strength? Does this suggest some threshold for a typhoon to trigger a phytoplankton bloom? Assuming that the horizontal advection could be neglected, we define the TBW as the wind speed of a typhoon at the longitude-latitude of the phytoplankton bloom after the typhoon's passage. By comparing the TBW of 4 typhoons and the MLD before the typhoons (Tables $1 \& 2$ ), we found that the TBW varies with MLD. A thicker mixed layer requires a higher wind speed for a typhoon to trigger a phytoplankton bloom. This could be partly explained by a model result that sea-surface cooling weakens as MLD increases from 10 to $50 \mathrm{~m}$ (Bao et al. 2000), and cold water below the mixed layer is generally nutrient rich, although the nutrient availability is likely to change both spatially and temporally. For analysis we need more data on typhoon blooms to understand the TBW as a function of MLD.

Table 3. Time lag between tropical cyclones and phytoplankton blooms, and threshold bloom-triggering wind speed at different mixed layer depths. Cat.: category on the Saffir-Simpson scale; B and A: before and after typhoon passage, respectively; SST: sea-surface temperature; MLD: mixed layer depth before typhoon; TBW: maximum sustained wind speed needed to trigger an offshore phytoplankton bloom; SCS: South China Sea

\begin{tabular}{|c|c|c|c|c|c|c|c|c|c|c|c|}
\hline \multirow[t]{2}{*}{ Location } & \multicolumn{3}{|c|}{ Typhoon } & \multicolumn{2}{|c|}{$\operatorname{SST}\left({ }^{\circ} \mathrm{C}\right)$} & \multicolumn{2}{|c|}{ Chl a $\left(\mathrm{mg} \mathrm{m}^{-3}\right)$} & \multirow{2}{*}{$\begin{array}{c}\text { Time } \\
\text { lag (d) }\end{array}$} & \multirow{2}{*}{$\begin{array}{c}\text { MLD } \\
(\mathrm{m})\end{array}$} & \multirow{2}{*}{$\begin{array}{l}\text { TBW } \\
\left(\mathrm{m} \mathrm{s}^{-1}\right)\end{array}$} & \multirow[t]{2}{*}{ Source } \\
\hline & Name & Cat. & Date & B & A & $\mathrm{B}$ & A & & & & \\
\hline \multirow[t]{2}{*}{ Gulf of Mexico } & Ivan & 4 & Sep 2004 & 29.2 & 25.4 & $\sim 0.36$ & $\sim 0.81$ & 3 & $50-60$ & $\sim 60$ & Walker et al. (2005) \\
\hline & & & & 28.9 & 24.8 & $\sim 0.24$ & $\sim 0.99$ & 4 & & & \\
\hline Arabian Sea & No name & & May 2001 & & 23.7 & $0.1-0.4$ & $5-8$ & 4 & $15-25$ & $\sim 30$ & Subrahmanyam et al. (2002) \\
\hline SCS & Kai-Tak & 2 & Jul 2000 & 30.7 & 22.7 & 0.1 & $<30$ & 6 & $20-30$ & $\sim 30$ & Lin et al. (2003) \\
\hline SCS & Damrey & 2 & Sep 2005 & 28.9 & 24.5 & $<0.15$ & $<4.1$ & 5 & $\sim 40$ & $\sim 33$ & This study \\
\hline
\end{tabular}




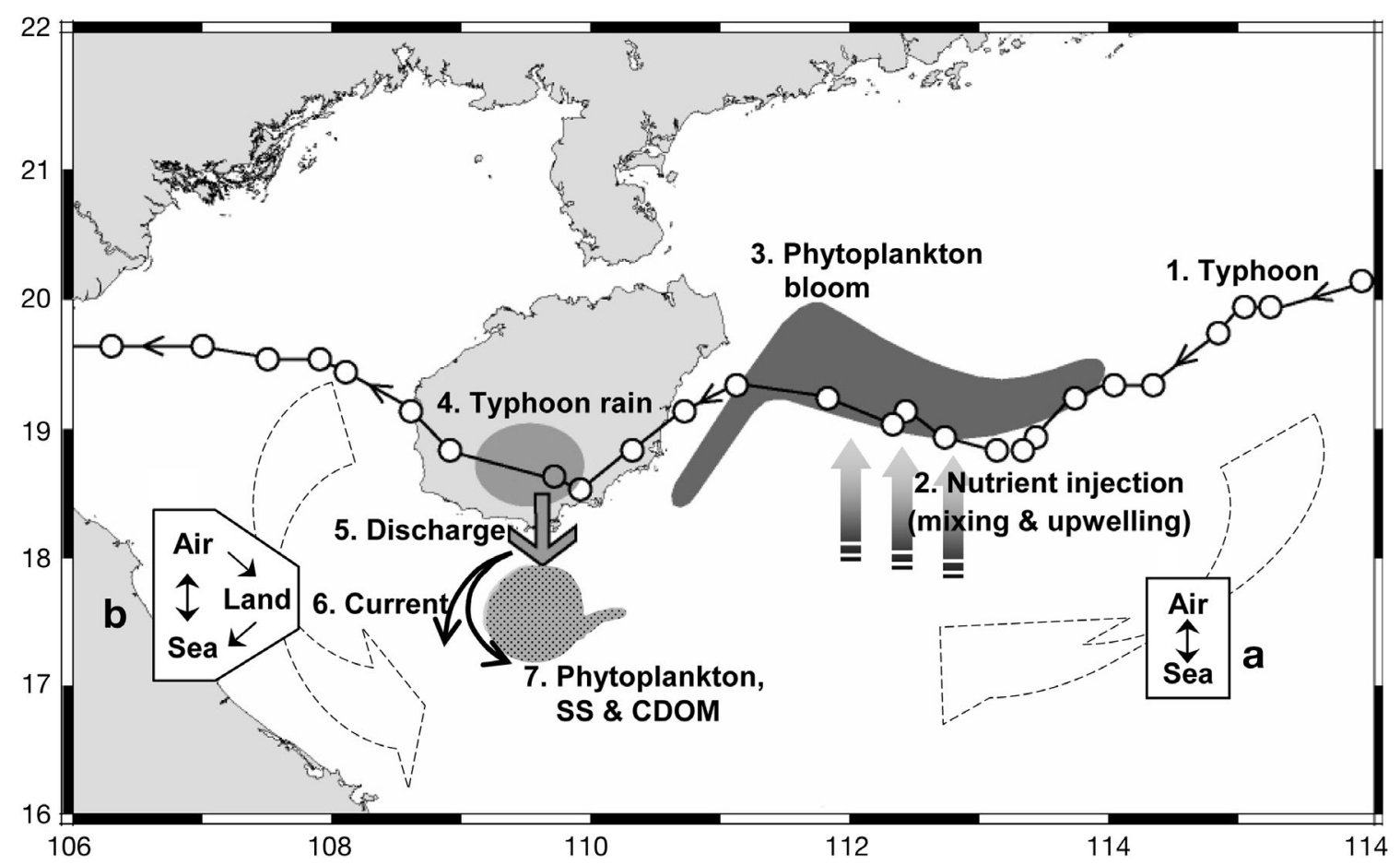

Fig. 9. Mechanism of chl a anomalies induced by the typhoon in the SCS. a: Typhoon (1) injected nutrients along its track (2), which triggered an offshore phytoplankton bloom (3). b: Typhoon rain over the island (4) resulted in runoff discharge into the SCS (5); typhoon-induced current (6) subsequently transported the brackish-water plume with SS, phytoplankton, and CDOM seaward (7)

Is it a general rule that a thicker mixed layer requires a higher bloom-triggering wind speed? If this is so, do hurricanes in the Atlantic Ocean (where the mixed layer is thickest; Dietrich et al. 1980) need to be stronger than those in Pacific and Indian Oceans to induce phytoplankton blooms of similar magnitude? Answering these questions may help to improve our understanding of the contribution of typhoons to new primary production, as well as the phytoplankton feedback to enhanced typhoon activity, which might be related to global warming.

\section{Nearshore chl a anomaly}

Chl a anomaly after typhoon rain

The nearshore chl a anomaly ('b' in Fig. 5B10-11) appeared near the southern tip of HNI, where the largest daily rainfall (>300 mm; Fig. 5C6) was brought about by the typhoon. Due to the steep topography, the transport of rainwater from this watershed into the ocean would have been quick. In fact, weak sea-surface cooling $\left(0.6^{\circ} \mathrm{C}_{;}\right.$' $\mathrm{b}$ ' in Fig. 5A7) emerged $1 \mathrm{~d}$ after the heaviest rainfall, at the same position where chl a increased several days later. It is likely that rainwater runoff had been discharged from southern HNI into this nearshore area, where SS, phytoplankton, and CDOM all increased significantly (Tables 1 \& 2, 'b' in Fig. 8). Although the high levels of SS and CDOM indicate overestimation of chl a concentration, they suggest favorable conditions for phytoplankton in 2 ways: (1) Due to the terrestrial origin, an increased load of nutrient is possible. (2) CDOM is a bio-protectant by absorbing harmful ultraviolet radiation (Sathyendranath 2000).

\section{Unique typhoon rain}

Despite the large amount of rainfall, the rainwater discharge might not be able to spread as far from the coast without a typhoon-induced current (reflected by the chl a pattern, 'b' in Fig. 4B). Seaward-extending chl a filaments carried by typhoon-induced eddies have been observed before (Davis \& Yan 2004, Yuan et al. 2004, Walker et al. 2005), indicating that the typhoon often induces offshore flows. Typhoon rain, therefore, is more able to influence offshore water than normal rain discharge, which tends to be confined to the coastal shelf. 


\section{Summary}

1. The present study demonstrates a series of ecological consequences related to the typhoon; these occurred in 2 phases (Fig. 9): an offshore phytoplankton bloom was fueled by vertical mixing and upwelling ('a' in Fig. 9) and a nearshore, seaward flux of SS, phytoplankton, and CDOM was triggered by rainwater runoff and advected by a typhoon-induced current ('b' in Fig. 9).

2. Typhoons also offer ideal cases for studying phytoplankton responses to mesoscale nutrient pulses that would not be possible by in situ study. The 3 to $6 \mathrm{~d}$ time lag between typhoon passage and the peak of the phytoplankton bloom may be the typical response time of the phytoplankton population to a sudden nutrient injection by typhoons.

3. The data of 4 typhoons show that thicker mixed layers need higher wind speeds for typhoons to trigger offshore phytoplankton blooms.

4. The offshore phytoplankton bloom and the greatest surface cooling appeared mainly to the right of Typhoon Damrey, while maximum rainfall appeared mainly on the left side.

5. An additional finding (tangential to the present study): SLA at the typhoon center increased (to 42 $\mathrm{cm}$ ) and decreased (to $-26 \mathrm{~cm}$ ) $1 \mathrm{~d}$ post-typhoon.

Acknowledgements. The present research was supported by the following grants to D.L.T.: Chinese Academy of Sciences (CAS) (KZCX3-SW-227-3), National Natural Science Foundation of China (NNSFC40576053), 'The One Hundred Talents Program' (YQ0302001) and the International Group Innovative Project of CAS, China. In situ data (CTD) were observed during an open research cruise in September 2005 supported by the South China Sea Institute of Oceanology, Chinese Academy of Sciences. We thank NASA's Ocean Color Working Group for providing Modis and SeaWiFS data, Remote Sensing Systems for TMI-AMSRE sea-surface temperature and QuikScat wind-vector data, the Physical Oceanography Distributed Active Archive Center (PO.DAAC) for QuikScat wind stress, GES DAAC for TRMM accumulated rainfall data, and the Colorado Center for Astrodynamics Research (CCAR) Altimeter Data Research Group for sea-level anomaly data.

\section{LITERATURE CITED}

Babin SM, Carton JA, Dickey TD, Wiggert JD (2004) Satellite evidence of hurricane-induced phytoplankton blooms in an oceanic desert. J Geophys Res 109, C03043, doi:10.1029/2003JC001938

Baith K, Lindsay R, Fu G, McClain CR (2001) SeaDAS: data analysis system developed for ocean color satellite sensors. EOS Trans Am Geophys Union 82:202

Bao JW, Wilczak JM, Choi JK, Kantha LH (2000) Numerical simulations of air-sea interaction under high wind conditions using a coupled model: a study of hurricane development. Mon Weather Rev 128:2190-2210

Chang J, Chung CC, Gong GC (1996) Influences of cyclones on chlorophyll a concentration and Synechococcus abundance in a subtropical western Pacific coastal ecosystem. Mar Ecol Prog Ser 140:199-205

Davis A, Yan X (2004) Hurricane forcing on chlorophyll-a concentration off the northeast coast of the U.S. Geophys Res Lett 31, L17304, doi: 10.1029/2004GL020668

Dietrich G, Kalle K, Krauss W, Siedler G (1980) General oceanography, 2nd edn. Wiley, New York

Elsner JB, Liu K (2003) Examining the ENSO-typhoon hypothesis. Clim Res 25:43-54

Emanuel K (2005) Increasing destructiveness of tropical cyclones over the past 30 years. Nature 436:686-688

Fogel M, Aguilar C, Cuhel R, Hollander D, Willey J, Paerl H (1999) Biological and isotopic changes in coastal waters induced by Hurricane Gordon. Limnol Oceanogr 44: 1359-1369

Lin I, Liu WT, Wu C, Wong GTF and 5 others (2003) New evidence for enhanced ocean primary production triggered by tropical cyclone. Geophys Res Lett 30:1718

Maritorena S, Siegel DA, Peterson A (2002) Optimization of a semi-analytical ocean color model for global scale applications. Appl Optics 41:2705-2714

McGillicuddy DJ, Robinson AR, Siegel DA, Jannasch HW and 5 others (1998) Influence of mesoscale eddies on new production in the Sargasso Sea. Nature 394:263-266

Ning X, Chai F, Xue H, Cai Y, Liu C, Shi J (2004) Physical -biological oceanographic coupling influencing phytoplankton and primary production in the South China Sea. J Geophys Res 109:C10005, doi:10.1029/ 2004JC002365

O'Reilly JE, Maritorena S, Siegel D, O'Brien MC and 18 others (2000) SeaWiFS postlaunch calibration and validation analyses, Part 3. In: Hooker SB, Firestone ER (eds) NASA Tech. Memo. 2000-206892, Vol 11. NASA Goddard Space Flight Center, Greenbelt, MD

Price JF (1981) Upper ocean response to a hurricane. J Phys Oceanogr 11:153-175

Ren F, Gleason B, Easterling D (2002) Typhoon impacts on China's precipitation during 1957-1996. Adv Atmos Sci 19:943-952

Sathyendranath S (ed) (2000) Remote sensing of ocean color in coastal and other optically-complex waters. International Ocean Colour Coordinating Group (IOCCG) report, Vol 3. IOCCG Project Office, Dartmouth, Nova Scotia

Stanley BG, Christopher WL, Alberto MM, William MG (2001) The recent increase in Atlantic hurricane activity: causes and implications. Science 293:474-479

Subrahmanyam B, Rao KH, Rao NS, Murty VSN, Sharp RJ (2002) Influence of a tropical cyclone on chlorophyll $a$ concentration in the Arabian Sea. Geophys Res Lett 29:2051-2054

Tang DL, Kawamura H, Lee MA, Dien TV (2003) Seasonal and spatial distribution of chlorophyll $a$ and water conditions in the Gulf of Tonkin, South China Sea. Remote Sens Environ 85:475-483

Tang DL, Kawamura H, Dien TV, Lee MA (2004a) Offshore phytoplankton biomass increase and its oceanographic causes in the South China Sea. Mar Ecol Prog Ser 268:31-41

Tang DL, Kawamura H, Hai Doan-Nhu, Takahashi W (2004b) Remote sensing oceanography of a harmful algal bloom (HAB) off the coast of southeastern Vietnam. J Geophys Res 109, doi:10.1029/2003JC002045

Tang DL, Kawamura H, Shi P, Takahashi W, Guan L, Shimada T, Sakaida F, Isogushi O (2006) Seasonal phytoplankton blooms associated with monsoonal influences and coastal environments in the sea areas either side of the Indochina Peninsula. J Geophys Res 111, G01010, doi:10.1029/ 2005JG000050 
Walker ND, Leben RR, Balasubramanian S (2005) Hurricaneforced upwelling and chlorophyll a enhancement within cold-core cyclones in the Gulf of Mexico. Geophys Res Lett 32, L18610, doi:10.1029/2005GL023716

Webster PJ, Holland GJ, Curry JA, Chang HR (2005) Changes in tropical cyclone number, duration, and intensity in a warming environment. Science 309:1844-1846

Wessel P, Smith WHF (1998) New improved version of the Generic Mapping Tools released. EOS Trans Am Geophys Union 79:579

Editorial responsibility: Otto Kinne (Editor-in-Chief), Oldendorf/Luhe, Germany
Wu B (1990) A study on the circulation in shelf waters west to Zhujiang River mouth. V. Empirical computed value. J Oceanogr Taiwan Strait 9(4):331-337 (in Chinese)

Wu L, Wang B, Geng S (2005) Growing typhoon influence on east Asia. Geophys Res Lett 32, L18703, doi:10.1029/ 2005GL022937

Yuan J, Miller RL, Powell RT, Dagg MJ (2004) Storm-induced injection of the Mississippi River plume into the open Gulf of Mexico. Geophys Res Lett 31, L09312, doi:10.1029/ 2003GL019335

Submitted: June 6, 2006; Accepted: August 7, 2006 Proofs received from author(s): February 17, 2007 